Куц О. В., Зелендін Ю. Д., кандидати сільськогосподарських наук Інститут овочівництва і баштанництва НААН

Вітанов О. Д., доктор сільськогосподарських наук, професор

ННЦ «Інститут агрохімії та грунтознавства ім. О. Н. Соколовського»

\title{
ЗАЛЕЖНІСТЬ СПОЖИВАННЯ ЕЛЕМЕНТІВ ЖИВЛЕННЯ РОСЛИНАМИ ЦИБУЛІ РІПЧАСТОЇ ВІД СПОСОБІВ ЗРОШЕННЯ ТА ВНЕСЕННЯ ДОБРИВ
}

\author{
Рецензент - доктор сільськогосподарських наук В. Ю. Гончаренко
}

\begin{abstract}
В умовах Лівобережного Лісостепу України застосування краплинного зрошення на фоні внесення мінеральних добрив врозкид і локально дає можливість отримувати товарну врожайність ицибулі ріпчастої на рівні 28,4-28,6 m/2а. Саме такі елементи технології забезпечують найактивніше використання рослинами циибулі з мінеральних добрив азоту - 26-40\%, фосфору - 4-6 i калію - 16$33 \% .3$ підвищенням рівня урожайності зростає винос елементів живлення. За краплинного зрошення та локалізації внесення добрив споживання елементів живлення на формування одиниці врожаю становить 3,08 к2/m азоту, 1,07 к2/m фосфору та 1,74 к2/m калію.
\end{abstract}

Ключові слова: циибуля ріпчаста, краплинне зрошення, мінеральні добрива, локальне внесення, урожайність, винос, споживання, елементи живлення.

Постановка проблеми. За виносом елементів мінерального живлення цибуля ріпчаста поступається багатьом іншим овочевим рослинам, але через слаборозвинену кореневу систему вона досить вимоглива до вмісту їх у грунті. Залежно від грунтово-кліматичних умов вирощування норми внесення органічних і мінеральних добрив можуть змінюватися. Раціональна науково обгрунтована система застосування добрив дає змогу підвищити врожайність овочевих рослин на 30-50 \% без зниження якості продукції. Незбалансоване підвищення дози азоту за недостатнього забезпечення фосфором і калієм погіршує якість цибулин та їх лежкість [3-7].

Аналіз основних досліджень і публікацій, у яких започатковано розв'язання проблеми. Світовий досвід із використання краплинного поливу вказує, що за такого способу зрошення вода разом 3 елементами живлення (фертигаціі) подається до рослин краплинами й рівномірно розподіляється у грунті в зоні розташування кореневої системи. Краплинний полив сприяє збереженню структури грунту, раціональній витраті води, запобігає зволоженню поверхні рослин, а отже, ура- женню патогенами $[4,8]$. Однією 3 переваг краплинного зрошення є можливість використання для поливу мінералізованої води (2,5 г/л). Ефективність краплинного поливу залежить від грунтовокліматичних умов, виду рослини, що зрошується, мінерального складу поливної води тощо [2].

Мета досліджень - визначити винос і споживання рослинами цибулі ріпчастої основних елементів живлення залежно від різних способів зрошення та внесення добрив.

Методика проведення досліджень. Роботу 3 визначення виносу та споживання основних поживних елементів рослинами цибулі ріпчастої виконували шляхом проведення польових i лабораторних досліджень у лабораторіях адаптивного овочівництва та агрохімії Інституту овочівництва і баштанництва НААН протягом 20062007 pp. відповідно до «Методики дослідної справи в овочівництві та баштанництві», 2001 [1]. У досліді вивчали: способи зрошення (фактор А) - без зрошення (абсолютний контроль), дощування 80-75 і 70-65 \% НВ (стандарт), краплинний (80-75 і 70-65 \% НВ) і способи внесення добрив (фактор В) - без добрив (контроль), внесення добрив врозкид $\left(\mathrm{N}_{120} \mathrm{P}_{180} \mathrm{~K}_{120}\right)$, локальне внесення добрив $\left(\mathrm{N}_{30} \mathrm{P}_{90} \mathrm{~K}_{60}+\right.$ фертигація $\left.\mathrm{N}_{30}\right)$. Ці елементи накладали один на один «методом клітки» («всі варіанти по всіх»). Площа облікової ділянки - $10 \mathrm{~m}^{2}$. Повторність у досліді - чотириразова. Грунт дослідної ділянки - чорнозем опідзолений середньосуглинковий лучнуватий (за даними ННЦ «Інститут грунтознавства і агрохімії ім. О. Н. Соколовського» НААН). Потужність гумусового профілю - 94 см. Вміст гумусу в орному шарі (0-30 см) - 3,26 \%, у підорному (30-50 см) - 3,00 \%. Грунт - незасолений, несолонцюватий, малогумусний, зі сприятливими водно-фізичними властивостями. Рівень забезпеченості доступними формами фосфору й калію - підвищений. Технологія вирощування цибулі ріпчастої - загальноприйнята для Лівобережного Лісостепу України в умовах зрошення. 
Результати досліджень свідчать про високу ефективність використання мінеральних добрив як у богарних умовах, так і при зрошенні (табл. 1).

Найбільший ефект від внесення добрив спостерігали на фоні краплинного зрошення. Приріст товарної урожайності від внесення добрив врозкид та локально на краплинному зрошенні становив 5,5-5,7 т/га. За поливу дощуванням на фоні внесення мінеральних добрив додатково одержано 4,4-5,5 т/га товарної продукції цибулі. Найнижчу ефективність внесення добрив відмічено в богарних умовах; прирости від добрив становили 2,0-2,1 т/га.

У середньому за роки досліджень вміст азоту в цибулинах коливався у межах 1,26-2,79 \%, фосфору $-0,67-0,90 \%$, калію $-0,82-1,57 \%$, у листковій масі, відповідно, 0,35-2,63\%, 0,24-0,70 і 0,27$1,15 \%$. Відмічено закономірність збільшення вмісту азоту та зменшення вмісту калію в рослинах за внесення добрив на зрошуваних фонах. Мінеральні добрива та способи зрошення не впливали на вміст фосфору в цибулинах та листковій масі рослин. На зрошуваних варіантах зафіксовано менший вміст азоту в листковій масі порівняно з незрошуваним фоном.

Зростання урожайності та відносного вмісту основних елементів живлення у цибулинах і в листках за використання добрив і зрошення сприяє збільшенню виносу поживних речовин як загального, так і з продуктивною частиною урожаю. Найбільшу інтенсивність поглинання і виносу елементів живлення визначено в разі використання добрив за краплинного зрошення, а саме: залежно від системи удобрення винос азоту становив 44,1-66,2 кг/га, фосфору - 28,6-31,2 і калію - 31,7-48,8 кг/га. На абсолютному контролі (без добрив та зрошення) винос продуктивною частиною урожаю становив для азоту 28,5 кг/га, фосфору - 7,3, калію 10,7 кг/га. За внесення повної дози мінеральних добрив врозкид винос елементів живлення з урожаєм цибулі перевищував дані з локального застосування половинної дози добрив.

\section{1. Винос елементів живлення рослинами цибулі ріпчастої сорту Глобус залежно від способів зрошення та удобрення (середнє за 2006-2007 рр.)}

\begin{tabular}{|c|c|c|c|c|c|c|c|c|}
\hline \multirow{2}{*}{$\begin{array}{c}\text { Спосіб } \\
\text { зрошення }\end{array}$} & \multirow{2}{*}{$\begin{array}{c}\text { Спосіб } \\
\text { удобрення }\end{array}$} & \multirow{2}{*}{$\begin{array}{c}\text { Урожай- } \\
\text { ність, } \\
\text { т/га }\end{array}$} & \multicolumn{3}{|c|}{$\begin{array}{c}\text { Винос продуктовою } \\
\text { частиною, кг/га }\end{array}$} & \multicolumn{3}{|c|}{$\begin{array}{c}\text { Загальний винос, } \\
\text { кг/га }\end{array}$} \\
\hline & & & $\mathrm{N}$ & $\mathrm{P}_{2} \mathrm{O}_{5}$ & $\mathrm{~K}_{2} \mathrm{O}$ & $\mathrm{N}$ & $\mathrm{P}_{2} \mathrm{O}_{5}$ & $\mathrm{~K}_{2} \mathrm{O}$ \\
\hline \multirow{3}{*}{ Без зрошення } & $\begin{array}{l}\text { без добрив } \\
\text { (контроль) }\end{array}$ & 8,8 & 28,5 & 7,3 & 10,7 & 38,0 & 10,6 & 17,9 \\
\hline & врозкид & 10,8 & 42,6 & 12,0 & 13,3 & 46,6 & 14,1 & 20,2 \\
\hline & локально & 10,9 & 28,3 & 10,2 & 13,8 & 40,4 & 12,7 & 19,8 \\
\hline \multirow{3}{*}{ Дощування } & без добрив & 15,9 & 34,6 & 17,3 & 24,1 & 44,0 & 22,0 & 40,8 \\
\hline & $\begin{array}{c}\text { врозкид } \\
\text { (стандарт) }\end{array}$ & 20,3 & 42,8 & 19,4 & 29,2 & 72,3 & 28,3 & 49,5 \\
\hline & локально & 21,4 & 35,8 & 22,4 & 34,4 & 75,7 & 2873 & 53,5 \\
\hline \multirow{3}{*}{$\begin{array}{c}\text { Краплинне } \\
\text { зрошення }\end{array}$} & без добрив & 22,9 & 44,1 & 28,6 & 31,7 & 63,8 & 37,0 & 49,0 \\
\hline & врозкид & 28,6 & 49,7 & 31,2 & 48,8 & 95,3 & 43,3 & 67,7 \\
\hline & локально & 28,4 & 62,2 & 28,8 & 36,5 & 80,9 & 41,4 & 68,9 \\
\hline
\end{tabular}

2. Споживання елементів живлення рослинами цибулі ріпчастої та коефіцієнти ӥх використання з добрив залежно від способів зрошення та удобрення (середн за 2006-2007 рр.)

\begin{tabular}{|c|c|c|c|c|c|c|c|}
\hline \multirow{2}{*}{$\begin{array}{c}\text { Спосіб } \\
\text { зрошення }\end{array}$} & \multirow{2}{*}{$\begin{array}{c}\text { Спосіб } \\
\text { удобрення }\end{array}$} & \multicolumn{2}{|c|}{$\begin{array}{c}\text { Коефіцієнт використання еле- } \\
\text { ментів живлення з добрив, \% }\end{array}$} & \multicolumn{3}{|c|}{ Загальне споживання, на т } \\
\cline { 2 - 8 } & & $\mathrm{N}$ & $\mathrm{P}_{2} \mathrm{O}_{5}$ & $\mathrm{~K}_{2} \mathrm{O}$ & $\mathrm{N}$ & $\mathrm{P}_{2} \mathrm{O}_{5}$ & $\mathrm{~K}_{2} \mathrm{O}$ \\
\hline \multirow{3}{*}{ Без зрошення } & без добрив (контроль) & - & - & - & 4,32 & 1,20 & 1,63 \\
\cline { 2 - 8 } & врозкид & 7 & 2 & 2 & 4,31 & 1,31 & 1,48 \\
\cline { 2 - 8 } & локально & 4 & 2 & 3 & 3,71 & 1,16 & 1,39 \\
\hline \multirow{3}{*}{ Дощування } & без добрив & - & - & - & 2,77 & 1,38 & 1,85 \\
\cline { 2 - 8 } & врозкид (стандарт) & 16 & 4 & 7 & 3,56 & 1,39 & 1,77 \\
\cline { 2 - 8 } & локально & 26 & 7 & 21 & 3,54 & 1,32 & 1,64 \\
\hline \multirow{2}{*}{$\begin{array}{c}\text { Краплинне } \\
\text { зрошення }\end{array}$} & без добрив & - & - & - & 2,79 & 1,19 & 1,66 \\
\cline { 2 - 8 } & врозкид & 26 & 4 & 16 & 3,33 & 1,06 & 1,72 \\
\cline { 2 - 8 } & локально & 40 & 6 & 33 & 3,08 & 1,07 & 1,74 \\
\hline
\end{tabular}


Подібну тенденцію спостерігали й за змінами величини загального виносу азоту, фосфору та калію залежно від способів зрошення та внесення добрив. На абсолютному контролі загальний винос азоту становив 38,0 кг/га, фосфору 10,6 кг/га, калію - 17,9 кг/га. Рослини цибулі ріпчастої найбільше споживали елементів живлення на фоні краплинного зрошення за внесення добрив врозкид (азоту - 95,3 кг/га, фосфору - 43,3 кг/га, калію - 67,7 кг/га) та локально (азоту - 80,9 кг/га, фосфору $-41,4$ кг/га, калію - 68,9 кг/га).

Встановлено, що зрошення сприяє кращому використанню рослинами цибулі ріпчастої елементів живлення $з$ добрив (табл. 2).

Найактивніше їх споживання зафіксовано за краплинного поливу в разі внесення добрив локально: використання азоту становить $40 \%$, фосфору -6 і калію - $33 \%$. Слід відмітити, що в богарних умовах спосіб внесення добрив не впливає на зміну коефіцієнта використання поживних речовин із добрив.

На контрольному варіанті на формування 1 т товарної продукції цибулі ріпчастої витрачається 4,32 кг азоту, 1,20 кг фосфору та 1,63 кг калію. Зрошення сприяє зменшенню споживання на формування одиниці врожаю цибулі азоту й збільшує

\section{БІБЛІОГРАФІЯ}

1. Методика дослідної справи в овочівництві і баштанництві / За ред. Г. Л. Бондаренка, К. І. Яковенка. - Х. : Основа, 2001. - 369 с.

2. Орошаемое овощеводство / C. А. Дудник, А. В. Антонов, Г. Е. Березкина [и др.]; под ред. С. А. Дудника. - К. : Урожай, 1990. - 240 с.

3. Панников В. Д. Почва, климат, удобрение и урожай / В. Д. Панников, В. Г. Минеев. - М. : Колос, 1977. $-416 \mathrm{c}$.

4. Ромащенко М. Капельное орошение репчатого лука / М. Ромащенко, А. Шатковский // Овощеводство. - 2008. - №3. - С. 66-68.

5. Севастьянова В. В. Вплив добрив на поживний режим грунту і врожай культур в овочевій сівозміні (повідомлення четверте) / В. В. Севас- споживання калію. Так, на варіантах без зрошення споживання азоту становило $3,71-4,32$ кг/т, за поливу дощуванням - 2,77-3,56 кг/т, за краплинного зрошення - 2,79-3,33 кг/т. Споживання калію на фоні без зрошення залежно від системи удобрення коливалося в межах 1,39-1,63 кг/т, за поливу дощуванням - 1,64-1,85 кг/т, за краплинного зрошення - 1,66-1,74 кг/т. Споживання фосфору істотно зменшувалося за використання краплинного зрошення.

Висновки. Використання зрошення та внесення добрив сприяє зростанню товарної урожайності цибулі ріпчастої. Найвищий рівень урожайності цибулі отримано на фоні краплинного зрошення за внесення добрив врозкид і локально $(28,4-28,6$ т/га). Зростання урожайності цибулі посилює винос елементів живлення 3 грунту та добрив, однак у цьому разі використання елементів живлення на формування одиниці урожаю у більшості випадків зменшується (виключенням $\epsilon$ зростання споживання калію за використання зрошення). За використання добрив локально на фоні дощування та краплинного зрошення відмічається найбільше використання 3 добрив азоту (26-40\%), фосфору (6-7\%) та калію (21-33 \%).

тьянова, В. Ю. Гончаренко, Л. П. Ходєєва, Л. О. Ткач // Овочівництво і баштанництво : зб. К. : Урожай, 1977. - Вип. 22. - С. 22-28.

6. Удобрение овощных культур : справочное руководство / Г. Г. Вендило, Т. А. Миканаев, В. Н. Петриченко, А. А. Скаржинский. - М. : Агропромиздат, 1986. - С. 51-82.

7. Bauer J. Erfahrungen mit der Tropfberegnung im Praxiseinsatz / J. Bauer // Rhein. Mscher. Gemuse obst Schnittblumen. - 1979. - V. 67, №7. - P. 367369.

8. Bhalla P., Tambi K. Influence of varying plant densities with different levels of nitrogen and potassium in onion (Allium cepa L.) // Seeds farms. 1982. - V.8. - №6. - P. 73-78. 